\title{
Irrelevance of Competitive Advantage for the Benefits of International Trade
}

\author{
Eckhard Siggel
}

Department of Economics, Concordia University, Montreal, Canada

\begin{abstract}
International competitiveness is often regarded as crucial for the attainment of gains from trade, which may lead policy makers to subsidize exports. This view is based on confusion between the concepts of competitive and comparative advantage. The paper argues that when comparative advantage is defined and measured appropriately, not limiting it to the Ricardian and Heckscher-Ohlin models, it becomes a necessary condition for the attainment of gains from trade and it applies to all forms of trade that lead to economy-wide gains. The paper proceeds by reviewing first the concepts and measurements of comparative and competitive advantage. It shows that in order to result in economy-wide benefits, known as gains from trade, trade needs to be based on comparative advantage. It also points to implications for the design of trade and industrial policies.
\end{abstract}

JEL Classification: F10, F12.

Keywords: Comparative advantage, Competitive advantage, International competitiveness, Gains from trade, Intra-industry trade.

\section{INTRODUCTION}

International competitiveness has gained much attention in the business literature as well as among policy makers in recent years. One of the leading advocates for the importance of the concept and its measurement is Michael Porter. As the title of Porter's original book [1] suggests, the concept of competitive advantage ${ }^{1}$ is given an economy-wide dimension. Although it mainly applies at the firm level, it is also used by Porter and others to analyse competitiveness at the national level and to recommend trade and industrial policies. This is unfortunate as it diverts attention away from the original concept of comparative advantage and tends to blind policy makers to the fact that the true benefits of trade to economies depend on comparative rather than competitive advantage.

The confusion between competitive and comparative advantage is also visible in the mainstream literature on international economics, which distinguishes 'comparative advantage trade' and 'other trade not based on comparative advantage', such as intra-industry trade. ${ }^{2}$

This paper argues that the gains from trade to the whole economy require the existence of comparative advantage for

*Address correspondence to this author at the Department of Economics, Concordia University, Montreal, Canada; Tel: 514- 848-2424, Ext. 3914; E-mail: Eckhard.siggel@concordia.ca

${ }^{1}$ The terms competitiveness and competitive advantage are being used here synonymously, as in Porter [1].

${ }^{2}$ This distinction is made in most textbooks on international trade. It is most explicit in Gerber [2], where intra-industry trade is introduced under the heading "Beyond comparative advantage" and it is stated that "a large share of international trade is not based on comparative advantage".

exports and of comparative disadvantage for imports, and that competitive without comparative advantage will not lead to gains from trade. ${ }^{3}$ It also shows that the concept of comparative advantage applies to all forms of trade, irrespective of the different sources of comparative advantage. When reviewing the various attempts of measuring comparative advantage, one realizes the importance of distinguishing competitive from comparative advantage and their different sources, in particular with regard to the gains from trade. Socio-economic net benefits arise only when specialization and trade are based on comparative advantage, not on simple cost competitiveness. If one subscribes to the general definition of comparative advantage, rather than the more restricted definition linking it strictly to productivity and/or endowment differences, it follows that intra-industry trade also requires comparative advantage in order to benefit an economy.

The paper proceeds by first clarifying the difference between comparative and competitive advantage, as well as their measurement. In section 3 it is shown that the attainment of gains from trade in the socio-economic sense requires comparative advantage. In section 4 it is argued that in intra-industry trade comparative advantage comes from economies of scale combined with other factors of location. Section 5 deals with some of the potential policy implications and section 6 concludes.

\section{COMPETITIVENESS AND COMPARATIVE ADV- ANTAGE REVISITED}

The statement that "trade is driven by comparative advantage" is often heard and rarely contested. In a strict

\footnotetext{
${ }^{3}$ This holds notwithstanding second-best arguments that under certain
conditions export subsidies can be welfare-improving, such as Brander and

${ }^{3}$ This holds notwithstanding second-best arguments that under certain
conditions export subsidies can be welfare-improving, such as Brander and Spencer [3].
} 
sense, however, it is misleading. In real-world economies, in which policy-induced and other distortions exist, trade is driven by the profit motive and cost competitiveness (for exports) or the lack of it (for imports). Clearly, firms or industries are exporting products and services when they are able to compete with foreign suppliers. However, competitiveness does not necessarily lead to gains from trade for the whole economy, because exports may be profitable due to subsidies or other beneficial distortions. In that case the gains from trade may be completely or partially cancelled.

Since the seminal paper of Dornbusch, Fisher and Samuelson [4] we know that the extension of the comparative advantage paradigm from the two-good to the n-good case requires the introduction of prices and monetary costs. We also know that the notion of opportunity cost is ambiguous in the real world of multiple products and that in the presence of multiple products it needs to be replaced by the requirement of undistorted equilibrium prices. When the observable prices are not distortion-free a cost advantage can only be described as cost competitiveness, not comparative advantage. This follows from the following argument, based on the Ricardian model extended to multiple products. In this model industries are competitive when their relative labour productivity exceeds the relative wage. When the general wage level rises beyond its equilibrium level it is possible that the country loses competitive advantage in all activities. That, however, is not possible for comparative advantage, by nature of the very concept. But it is possible that all activities are, temporarily, non-competitive. In other words, the nominal changes of prices, wages or the exchange rate out of equilibrium affect only competitive but not comparative advantage.

It is common in the presentation of the Ricardian trade model to derive equilibrium wages from the prices under free trade. In the Ricardian model extended to $\mathrm{n}$ products it is the relative equilibrium wage that represents the dividing line between activities that have comparative advantage and those that have not. When applying the condition that relative labour productivity (relative to the foreign one) needs to exceed the relative wage, it is silently assumed that the wages need to be undistorted equilibrium wages; otherwise the condition can only be called cost competitiveness:

a w $<\mathrm{a}^{*} \mathrm{w}^{*}$ or $\mathrm{a} * / \mathrm{a}>\mathrm{w} / \mathrm{w}^{*}$ (competitiveness)

a we $<\mathrm{a}^{*} \mathrm{we}^{*}$ or $\mathrm{a}^{*} / \mathrm{a}>\mathrm{we} / \mathrm{we}^{*}$ (comparative advantage),

where a and $\mathrm{a}^{*}$ are domestic and foreign $(*)$ labour input per unit of output, $\mathrm{w}$ and $\mathrm{w}^{*}$ are domestic and foreign wage rates and we and we* are undistorted equilibrium wage rates. In the Heckscher-Ohlin model it is the direct correspondence between relative product and factor prices in equilibrium that allows us to determine the equilibrium factor prices which lead to gains from trade. The fact that the equilibrium nature of factor prices is often not underlined derives from the nature of reasoning, which is based on the two-sector general equilibrium model under perfect competition, full employment and free trade. It needs to be stated, however, that in the real world product and factor prices are not necessarily equilibrium prices and need to be adjusted in order to be usable for the determination of comparative advantage. ${ }^{4}$ This leads to a further source of controversy, the neglect of measurement of comparative and competitive advantage.

The failure to distinguish the two concepts, of competitive and comparative advantage, has had several consequences. With respect to competitiveness, the absence of a well-established concept has led to a multitude of definitions in the literature, which was surveyed recently [5]. Many indicators have been proposed and those of a macroeconomic perspective, such as the method used by the World Economic Forum in its annual World Competitiveness Report [6], differ distinctly from the original meaning of competitive advantage (cost competitiveness) in the microeconomic sense. With regard to comparative advantage, the official discourse of trade theory has continued to explain the concept strictly in Ricardian terms, i.e. with reference to two goods and one factor of production. The extension to more than two products and to more than one factor, in the framework of the Heckscher-Ohlin trade theory, is acknowledged but usually not pursued in terms of measurement. The comparative advantage principle applied to the Heckscher-Ohlin model requires that in autarchy the domestic prices differ from foreign or international ones. Since trade leads to the equalization of prices this difference disappears and comparative advantage becomes supposedly un-measurable. But does it mean that comparative advantage does not exist once trade takes place? And is it really unmeasurable in a post-trade context?

\subsection{Indicators of Competitiveness and Comparative Advantage}

Bela Balassa recognized in his often quoted paper on Revealed Comparative Advantage (RCA) [7], that the measurement of a comparative cost advantage by comparison between domestic and foreign prices under autarchy was impossible in reality, since autarchy prices are usually not observable. He proposed therefore to measure comparative advantage by help of the export performance of different activities. This proposal contributed to perpetuate the confusion between competitiveness and comparative advantage. Clearly, export performance in the context of distorted prices reflects cost competitiveness and not comparative advantage. It does not imply gains from trade to the economy. Therefore, the RCA measures competitive, but not comparative advantage.

The only rigorous measure of comparative advantage that has survived over time is the Domestic Resource Cost (DRC) ratio, proposed first by Michael Bruno [8]. It compares the cost of primary factor inputs with the corresponding value added, all computed at shadow prices. Its only disadvantage is that it enters the potential price advantage of intermediate inputs only indirectly through the denominator. Clearly, intermediate inputs can be a source of comparative advantage. For tradable inputs it can be argued

\footnotetext{
${ }^{4}$ The procedure requires estimation of shadow prices, just like in social costbenefit analysis.
} 
that their equilibrium prices are international prices and therefore the abundance of tradable raw materials cannot constitute a source of comparative advantage. This is debatable, but in the presence of transport cost the abundance or scarcity of resource inputs can lead to regional price differences even if they are tradable. For non-tradable intermediate inputs the argument clearly applies. For instance, abundant and low-cost domestic electricity supply can be a source of comparative advantage, especially in energy-intensive industries.

The preceding argument has led us to propose a full-cost measure of comparative advantage, which divides total cost of production by the output value (or price), both at shadow prices, and which we have called Unit Cost ratio at shadow prices (UCRs) [9]. This indicator lends itself also to a decomposition of the corresponding measure of domestic cost competitiveness (UCRd) into components of comparative advantage and various sources of distortion, in particular exchange rate misalignment, rates of protection of output and input prices, as well as various distortions of primary input prices (i.e. wage rates and the cost of capital). While these indicators are often difficult to apply, given their extensive data requirements and the necessity to estimate shadow prices of all inputs and outputs that are prone to price distortions, they highlight the crucial difference between competitiveness under protection, subsidies and/or other distortions on the one hand, and comparative advantage on the other hand. The distinction is of great importance, when it comes to industrial policies, public investment criteria and especially in the context of policies in favour of sustainable development.

One often wonders why the measurement of comparative advantage has not attracted more interest in the past, barring few exceptions, ${ }^{5}$ and has not led to the establishment of generally accepted indicators for the use in econometric studies of trade. The reason is probably the philosophy that underlies most works in mainstream economic theory. It places much confidence in markets, even when markets are possibly imperfect or failing. Governments are rightly said to be not competent in "picking winners", which means identifying those activities that have potential comparative advantage. But it is also true that de facto all governments engage in some forms of industrial policy. This means that better information about distortions of all kinds, about competitiveness and comparative advantage would help in choosing better policies, especially in the context of globalization and the pursuit of socio-economic objectives. We shall return to this issue in the section on policy implications.

\section{COMPARATIVE ADVANTAGE AND THE GAINS FROM TRADE}

It is well established in the literature that comparative advantage leads to gains from trade, meaning benefits to the whole economy. This may be interpreted as stating that comparative advantage is a sufficient condition for gains

\footnotetext{
${ }^{5}$ Most notable exceptions are [10] and [11], as well as replies and extensions in the same journal (WWA 1985,121(2), 351-4 and WWA 1986, 122(2), 379-81).
}

form trade to occur. The question that remains to be addressed is whether comparative advantage is also a necessary condition for the attainment of gains from trade. In other words: Can trade without comparative advantage lead to gains from trade?

The argument that comparative advantage is necessary for gains from trade to occur is easily demonstrated in the two-good framework of general equilibrium. In the standard diagram shown in Fig. (1) the real opportunity cost of producing either of the two goods, for instance that of X, which equals the slope of the production possibilities frontier (PPF), can be either lower or higher than the relative price of $\mathrm{X}$ at free trade $(\mathrm{Px} / \mathrm{Py})_{\mathrm{F}}$. If it is higher, $\mathrm{Y}$ is an exportable, and if it is lower, $X$ is an exportable. Since the original production point (A) in autarchy depends on preferences, A may lie on either side of the point $\mathrm{Q}_{\mathrm{F}}$, where production will take place under free trade. Here we assume that A lies to the right of $\mathrm{Q}_{\mathrm{F}}$, which determines that $\mathrm{Y}$ in this diagram is the exportable and $\mathrm{X}$ is the importable. When specialization in favour of the exportable occurs (move from $A$ to $\mathrm{Q}_{\mathrm{F}}$ ) and free trade takes place, it is obvious that gains from trade occur, moving the consumption point up from $\mathrm{A}$ to a higher level of welfare such as at $\mathrm{C}_{\mathrm{F}}$.

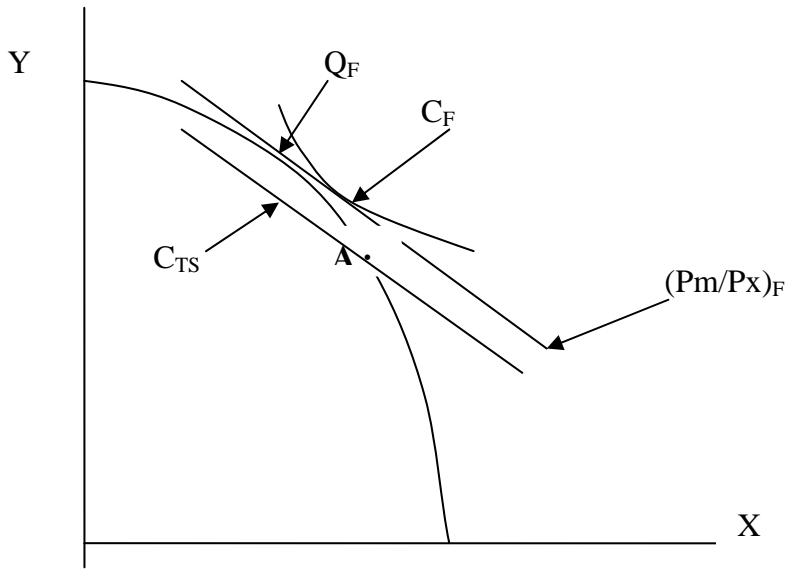

Fig. (1). Trade with and without comparative advantage.

Under trade restrictions, for instance a tariff on imports, specialization would not move the production point to $\mathrm{Q}_{\mathrm{F}}$, but to any point to its right. For simplicity, we can assume that it remains at A. Trade can nevertheless take place and even some gains from trade (but less than under free trade) are possible as long as the exportable is exported (consumption points to the right of A). If, however, the importable is exported and the exportable imported, the consumption point would lie to the left of A and the 'gains from trade' would clearly be negative as the consumption point would lie inside the PPF and on a lower indifference curve than at A. It is clear in this case that the necessary condition is the same for the gains from trade and comparative advantage. Trading against comparative advantage will clearly not lead to positive gains from trade.

In the case of more than two products this simple demonstration breaks down because opportunity cost is no longer unambiguous. The analysis then requires the 
introduction of prices and monetary costs, which in turn leads to the important distinction between competitive and comparative advantage. Also, the foregoing analysis assumes that costs are endogenous, such that the factor prices are domestic equilibrium prices determined by endowments and the demands resulting from domestic consumption and trade, although product prices are allowed to be policy-determined. It does not allow us to deal with the more realistic case of exogenously determined factor prices. In this case it is possible to find industries that have comparative advantage (exportables) but are unable to export due to non-competitive costs. It is therefore useful to apply unit cost analysis and to introduce the concept of international cost competitiveness or competitive advantage, meaning that unit costs at market prices are inferior to the international product price. The question to be examined is again whether gains from trade require comparative advantage.

By definition, importables are products whose costs at undistorted equilibrium prices are superior to their international price:

$\mathrm{UC}_{\mathrm{M}}^{\mathrm{S}} / \mathrm{P}_{\mathrm{M}}^{\mathrm{F}}>1$,

where $\mathrm{UC}$ refers to unit costs and the superscripts $\mathrm{S}$ and $\mathrm{F}$ refer to shadow and free trade prices, respectively, and where the former imply the absence of any distortion and the latter are assumed to be distortion-free. Now let us take the case of an importable product, and assume that its producer, in spite of absence of comparative advantage, succeeds in exporting with profit, due to costs in domestic prices that are inferior or equal to the international price:

$\mathrm{UC}_{\mathrm{M}}^{\mathrm{D}} / \mathrm{P}_{\mathrm{M}}^{\mathrm{F}} \leq 1$,

where the superscript D refers to (possibly distorted) domestic prices.

The resulting inequality

$\mathrm{UC}_{\mathrm{M}}^{\mathrm{S}} / \mathrm{P}_{\mathrm{M}}^{\mathrm{F}}>1 \geq \mathrm{UC}_{\mathrm{M}}^{\mathrm{D}} / \mathrm{P}_{\mathrm{M}} \mathrm{UC}_{\mathrm{M}}{ }^{\mathrm{F}}$

can hold only if the unit costs in domestic prices $\left(\mathrm{UC}_{\mathrm{M}}{ }^{\mathrm{D}}\right)$ are inferior to those at shadow prices $\left(\mathrm{UC}_{\mathrm{M}}^{\mathrm{S}}\right)$. This is highly unlikely since intermediate inputs tend to be cheaper under liberalization and so is the cost of capital. While normally $\mathrm{UC}_{\mathrm{M}}^{\mathrm{D}}$ tends to be larger than $\mathrm{UC}_{\mathrm{M}}^{\mathrm{S}}$, a substantial costreducing subsidy, $>\left(\mathrm{UC}_{\mathrm{M}}{ }^{\mathrm{D}}-\mathrm{UC}_{\mathrm{M}}{ }^{\mathrm{S}}\right)$, could achieve this result. However, such a subsidy would reduce the level of welfare and more than cancel the gains from trade, since the expected trade benefits are in the same order as the cost reduction when moving from autarchy to free trade. It follows that the gains from trade require comparative advantage.

Now consider the case of an exportable product, which under free trade has unit costs that are lower or equal to the international price, but which we assume to be nonprofitable when exported:

$\mathrm{UC}_{\mathrm{X}}{ }^{\mathrm{S}} / \mathrm{P}_{\mathrm{X}}{ }^{\mathrm{F}} \leq 1<\mathrm{UC}_{\mathrm{X}}{ }^{\mathrm{D}} / \mathrm{P}_{\mathrm{X}}{ }^{\mathrm{F}}$.

To make this kind of trade profitable the losses would have to be compensated by subsidies, which would cancel the gains from trade. We conclude again that the achievement of gains from trade requires comparative advantage.

\subsection{Limitations and Extensions of the Analysis}

This demonstration corresponds to the conventional analysis of tariffs and subsidies in a static generalequilibrium framework. It excludes dynamic effects and therefore dynamic gains from trade, which may possibly outweigh the potential welfare gains or losses from subsidization. Three kinds of dynamic gains can occur from exports: (a) diminished cost due to larger-scale production following trade liberalization, (b) diminished cost through learning by exporting and (c) access to new technology gained by way of increased imports, which in turn are made possible through increased exports. The achievement of such dynamic gains opens the door for the possibility that industries that presently have no comparative advantage be subsidized, allowing them to develop comparative advantage over time. The argument is familiar from the discussion of infant industry protection. On the other hand, the gains from trade are likely to be reduced when other objectives are factored into the social welfare function, such as environmental protection. The quantification of such effects is known to be difficult.

The arguments above apply of course to trade in general and they need to be considered in a complete evaluation of the gains from trade. In the present context they only modify but do not reverse our argument that without comparative advantage there cannot be gains from trade. Using the method of measuring comparative advantage that we have championed in the past, an industry in which the total cost at shadow prices exceeds the sum of private and social benefits, and which is made competitive by way of subsidies, cannot have positive net benefits, as demonstrated above.

\section{ECONOMIES OF SCALE, INTRA-INDUSTRY TRADE AND COMPARATIVE ADVANTAGE}

Economies of scale are not generally recognized as a source of comparative advantage. The reason for this may be the fact that scale economies are an industry characteristic and not a country characteristic. Since large markets tend to attract large plants and industries featuring economies of scale, Tybout argued, “...bigger economies have bigger plants, so large domestic markets may confer a competitive advantage on potential exporters through internal increasing returns to scale" [12]. As the author also reports gains from trade through specialization in large-scale production it follows that the increased competitiveness may translate into comparative advantage. Other authors who describe economies of scale as a source of comparative advantage are Markusen et al. [13].

As scale economies are a characteristic of industries in the same sense as capital intensity or labour intensity, they apply to industries independent of their location. In combination with country-specific attributes, such as country size or taste biases, they can generate comparative advantage. It must be conceded that as a source of comparative advantage economies of scale act differently from labour or capital abundance in that they are less ex- 
ante. They become factual only once the producers have chosen the location of production and the plant size. Let us now see how comparative advantage arises in intra-industry trade.

The model that simulates most cogently the forces leading to intra-industry trade is the monopolistic competition model developed by Helpman and Krugman [14]. This model is based on two important assumptions, those of differentiated (brand name) products implying monopolistic competition, and of economies of scale, which in turn derive from fixed start-up costs. Intra-industry trade arises in this model when firms producing brand-name products will rather produce in large-scale plants in one country and supply other countries by exporting than producing in smaller plants in various locations. Countries can therefore be exporters and importers of the same type of product if the homes of different brands are not all located in the same country. Where the home base of each brand is located is not explained by the model; nor does the model explain the location of the surviving plants when markets become integrated. There are other theories, however, which can provide an explanation of industry location, and which add to historical contingency. Taste patterns or preferences, for instance, can determine the origin of certain product brands. This approach has been further extended into a trade theory by Linder [15].

The essence of the intra-industry trade model is that the production of differentiated products will take place where the average cost is lowest and at the largest possible scale. Countries that either develop such industries or succeed in attracting them, can therefore derive comparative advantage based on scale economies, as long as comparative advantage is measured by comparative costs, as it should be, in line with the history of the concept. The model also reflects monopolistic competition, which results from product differentiation into brand-name products. The competition between the producers of different brands of similar products takes the form of mixed price/attribute competition. This raises the question whether comparative costs and, thereby, comparative advantage apply to differentiated products. It is possible that some of the rejections of comparative advantage in intra-industry trade may be based on a negative answer to this question. In our view, the comparison of costs of differentiated products poses no particular problem as it exists in inter-industry trade as well. Quality differences exist even in so-called homogeneous products; in other words, perfect homogeneity is rarely observable. Quality differences are then overcome by assuming that they are taken into account by product prices. In the measurement of competitiveness and comparative advantage discussed earlier, differences in product quality are taken into account by the particular definition of unit cost ratios, which divide total costs by the value of output. Higher quality or additional product attributes tend to increase both costs and the price. Consequently, unit cost ratios are comparable across differentiated products. It follows therefore that when comparative advantage (CA) is defined in the correct comprehensive way, i.e. not limited to Ricardian or HO-type sources, it applies as well to intra-industry trade and the distinction between CA-trade and non-CA-trade is meaningless.

\section{POLICY IMPLICATIONS}

The distinction and measurement of competitive and comparative advantage are not only important from an academic point of view; they are important for the rational design of industrial policies. It is often argued that industrial policies have no place in market-driven economies. Nevertheless, in nearly all countries governments de facto engage in industrial policies, either purposefully or accidentally by pursuing other goals. Often the outcome of such processes is a set of policies that is sub-optimal with regard to longer-term sustainable development. The pursuit of socio-economic objectives requires evaluation of benefits and costs, and in the context of international trade this amounts to information on competitiveness and comparative advantage. The following examples demonstrate the validity of this argument.

In a study of Kenyan manufacturing industries [16] it was found that several industries, which had comparative advantage, based on the unit cost ratio measurement, were unable to compete internationally, due to high costs. These costs were essentially the consequence of distortions imposed by government policies and the absence of compensation. Among the largest cost distortions were the cost of capital (due to extensive government borrowing), exchange rate overvaluation, excessive transport costs (due to decaying infrastructure), excessive energy costs (due to frequent electricity blackouts), as well as communication costs (due to failing telephone lines). Corrective or compensating policies could have helped these industries realize their comparative advantage and to compete internationally. Instead, we found that for a majority of manufacturing industries their international competitiveness had declined from the mid-eighties to the mid-nineties, in spite of some evidence of trade liberalisation during this period. These cases demonstrate the importance of analysing comparative and competitive advantages for the purpose of designing industrial strategies.

In an illuminating debate by Lin and Chang [17] the authors refer to cases of industries in Japan, South Korea and Finland, which exemplify the role of government support for technological upgrading. While agreeing on the value of such support for growth and development they disagree on the extent to which industrial strategies could deviate, temporarily, from comparative advantage in order to generate competitiveness in the future. The missing link in this debate, however, is measurement. Without quantification the impact of government support for future industrial champions remains ambiguous.

Are such arguments valid with regard to intra-industry trade as well? Take the case of a developing country interested in regional integration, the expansion of regional trade and industrialization. Also assume that the industrial structure of the country and its regional neighbours is very similar, due to similar resource endowment and similar industry policies in the past. Therefore, while chances for 
expanding inter-industry trade are limited, this is not the case for intra-industry trade. The leading industries, textile and food industries, as well as metal products, offer possibilities of specialization in different products. This may not happen automatically, but encouragement and some support may then help to generate intra-industry trade, and the consequence can be production in larger plants and lower costs due to economies of scale. The context described may apply to the East African countries, Kenya, Uganda, Tanzania, Rwanda and Burundi, who are in the process of developing a common market and possibly an economic union. An example of success in a different context, the one of Canada, is the Canada-US Auto Pact of the 1960s, in which the establishment of industry-specific free trade led to restructuring of the industry, significant cost decline and intra-industry trade between Canada and the US.

\section{CONCLUSION}

The present paper is motivated by two observations: First, the often heard claim that international competitiveness is the key to economy-wide gains, which leads to subsidization of exports. Second, the widely accepted division between comparative advantage trade and other trade not based on comparative advantage, in particular intraindustry trade. Both views are based on an overly narrow interpretation of comparative advantage, limiting it to Ricardian and Heckscher-Ohlin-type models, as well as on confusion between competitive and comparative advantage. It has been argued here that the two concepts are closely related, can be measured by unit cost/price ratios and differ only by the use of shadow prices, or undistorted equilibrium prices, in the case of comparative advantage. If this requirement is not met, economy-wide gains from trade are not guaranteed and policy makers may be led to subsidize importables in order to export, or to impose cost distortions on exportables preventing them to be exported. It is also shown that when the cost/price ratio definition is used to measure comparative advantage across differentiated products the comparative advantage principle applies to all forms of trade.

\section{ACKNOWLEDGEMENT}

\section{CONFLICT OF INTEREST}

The authors confirm that this article content has no conflicts of interest.

\section{REFERENCES}

[1] Porter M. The competitive advantage of nations. New York: Free Press 1990.

[2] Gerber J. International economics. Homewood, Ill: Richard D. Irwin 1981; p.84.

[3] Brander JA, Spencer BJ. Export subsidies and international market share rivalry. J Int Econ 1985; 18(1/2): 83-100.

[4] Dornbusch R, Fisher S, Samuelson P. Comparative advantage, trade and payments in a Ricardian model with a continuum of goods. Am Econ Rev 1977; 67: 823-39.

[5] Siggel E. International competitiveness and comparative advantage: a survey and a proposal for measurement. J Ind Competition Trade 2006; 6: 137-59.

[6] WEF/IMD. The World competitiveness report. Geneva and Lausanne: World Economic Forum and IMD 1995.

[7] Balassa B. Trade liberalization and 'revealed comparative advantage'. Manchester Sch Econ Soc Stud 1965; 33: 92-123.

[8] Bruno M. The optimal selection of export-promoting and importsubstituting projects, in: Planning the External Sector: Techniques, Problems and Policies 1965; United Nations, New York; and Domestic resource costs and effective protection: Clarification and Synthesis. J Polit Econ 1972; 80: 16-33.

[9] Siggel E. Concepts and measurement of competitiveness: toward an integrated approach. In: De Grauwe P, Ed. Dimensions of competitiveness, Cambridge: The MIT Press 2010; pp. 95-120.

[10] Bowen HP. On the theoretical interpretation of indices of trade intensity and revealed comparative advantage. Weltwirtsch Arch 1983; 119(3): 464-72.

[11] Balance RH, Forstner H, Murray T. On measuring comparative advantage: A note on Bowen's indices. Weltwirtsch Arch 1985; 121: 346-50.

[12] Tybout JR. Internal returns to scale as a source of comparativeaAdvantage: the evidence. Am Econ Rev 1993; 83(2): $440-4$.

[13] Markusen JR, Melvin JR, Kaempfer WH, Maskus KE. International Trade. Theory and Evidence. USA: McGraw-Hill 1995.

[14] Helpman E, Krugman P. Market structure and foreign trade. Cambridge: MIT Press 1985.

[15] Linder SB. An essay on trade and transformation. Stockholm: Almqvist \& Wicksell 1961.

[16] Siggel E, Ikiara G, Nganda B. Policy reforms, competitiveness and prospects of Kenya's manufacturing industries: 1984 - 1997. J Afr Finance Econ Dev 2002; 5(1): 72-104.

[17] Lin J, Chang H-J. DPR Debate: Should industrial policy in developing countries conform to comparative advantage or defy it? Dev Policy Rev 2009; 27(5): 483-502.

Declared none. 